\title{
Mexican Fruit Fly, Anastrepha ludens (Loew) (Insecta: Diptera: Tephritidae) ${ }^{1}$
}

\author{
H. V. Weems, Jr, J. B. Heppner, G. J. Steck, T. R. Fasulo and J. L. Nation ${ }^{2}$
}

\section{Introduction}

The Mexican fruit fly, Anastrepha ludens (Loew), is a very serious pest of various fruits, particularly citrus and mango, in Mexico and Central America. Its natural distribution includes the Rio Grande Valley of Texas, where populations routinely attain pest status if control measures are not practiced. It is a frequent invader in southern California and Arizona. Mexican fruit fly represents a particular threat to Florida because of its special affinity for grapefruit, of which Florida is one of the world's leading producers.

Although larvae are transported widely in infested fruits, the discovery of adults in Florida has been surprisingly rare. A single specimen was detected in a McPhail trap in Sarasota in 1972 which initiated an extensive survey program that yielded no further specimens (see Clark et al. 1996); and two specimens (one male and one female), labeled "Key West, 22-IX-34, at Spondias mombin Jacq., O.D. Link Coll., S.P.B. Acc. No. 52582" are present in the Florida State Collection of Arthropods. It was also detected in Florida in 2003, but did not proliferate.
This species is the only important member of the genus Anastrepha that is subtropical rather than tropical, occupying the northern portion of the range of the genus and extending southward only at the higher altitudes. A. ludens can withstand freezing weather well, whereas in hot areas it may be killed by the heat of the sun.

\section{Taxonomy}

The genus Anastrepha comprises about 200 species distributed throughout the Americas. Most species are characterized by their yellow to brown body and wing coloration, distinctive wing pattern of costal-, S-, and inverted V-bands (C, S, and V in Fig. 2 ), and females with relatively long, tubular ovipositor sheaths. The medial vein (M1) curves forward at the wing tip. Anastrepha ludens seems to be a well-defined and clearly distinct species, although there is a possibility of a separate but nearly indistinguishable form in the extreme southern part of its distribution in Costa Rica (Jiron et al. 1988). The first comprehensive treatment of Anastrepha taxonomy, which remains fundamental and useful, is that of Stone (1942).

1. This document is EENY-201 (originally published as DPI Entomology Circulars 16, 260 and 391), one of a series of Featured Creatures from the Entomology and Nematology Department, Florida Cooperative Extension Service, Institute of Food and Agricultural Sciences, University of Florida. Published: March 2001. Revised: June 2003, January 2004. This document is also available on Featured Creatures Website at http://creatures.ifas.ufl.edu. Please visit the EDIS Website at http://edis.ifas.ufl.edu.

2. H. V. Weems, Jr, J. B. Heppner, and G. J. Steck, Florida Department of Agriculture and Consumer Services, Division of Plant Industry; T. R. Fasulo and J. L. Nation, Entomology and Nematology Department, University of Florida, Gainesville, FL.

The Institute of Food and Agricultural Sciences (IFAS) is an Equal Employment Opportunity - Affirmative Action Employer authorized to provide research, educational information and other services only to individuals and institutions that function without regard to race, creed, color, religion, age, disability, sex, sexual orientation, marital status, national origin, political opinions or affiliations. For information on obtaining other extension publications, contact your county Cooperative Extension Service office. Florida Cooperative Extension Service / Institute of Food and Agricultural Sciences / University of Florida / Larry R. Arrington, Interim Dean 


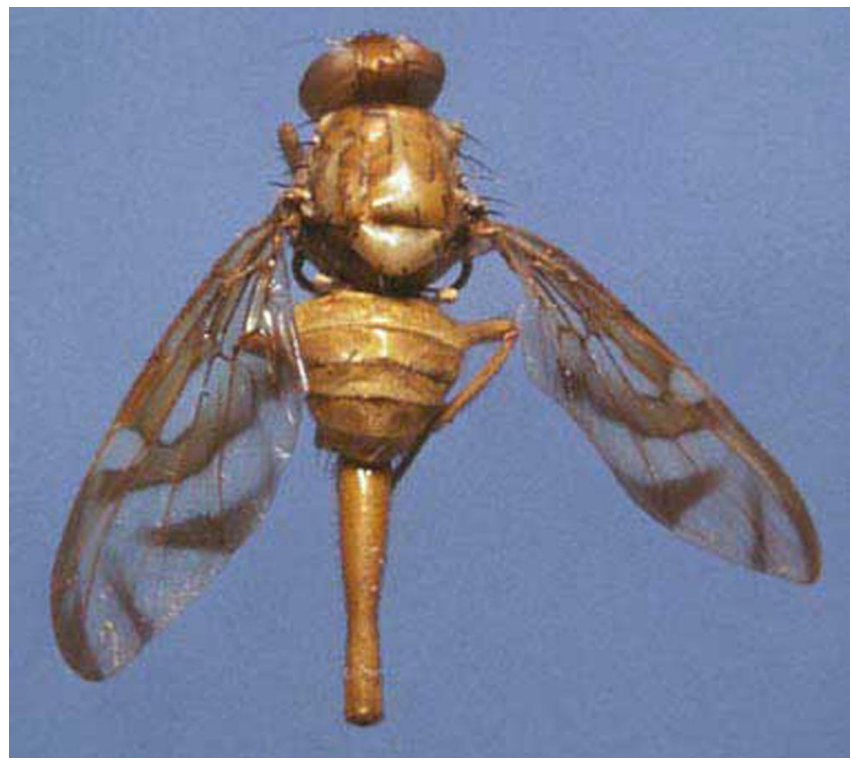

Figure 1. Adult female Mexican fruit fly, Anastrepha ludens (Loew). Credits: Jeffrey Lotz, Division of Plant Industry

This species has also been known as:

Acrotoxa ludens Loew

Trypeta ludens (Loew)

\section{Distribution}

The Mexican fruit fly is indigenous to Mexico and is found also in Central America and northern South America. It has spread also into the cultivated citrus sections of the west coast of Mexico and northward toward Texas, Arizona and California, resulting in continual detection, survey, and eradication campaigns in these areas.

\section{Identification}

\section{Adult}

The adult is slightly larger than a housefly and is mostly yellowish-brown in color. The Mexican fruit fly, A. ludens, is typical in appearance to other members of the genus Anastrepha, but notable for the female's long ovipositor and sheath relative to its body size. The ovipositor is 3.35-4.7 mm long. The Mexican fruit fly is readily distinguished from the Caribbean fruit fly, Anastrepha suspensa (Loew), by its much longer ovipositor (only 1.45-1.6 mm long in suspensa), wing band color (pale yellow in ludens vs. dark brown in suspensa), width of S-band (narrow apically, not extending to medial vein in ludens vs.

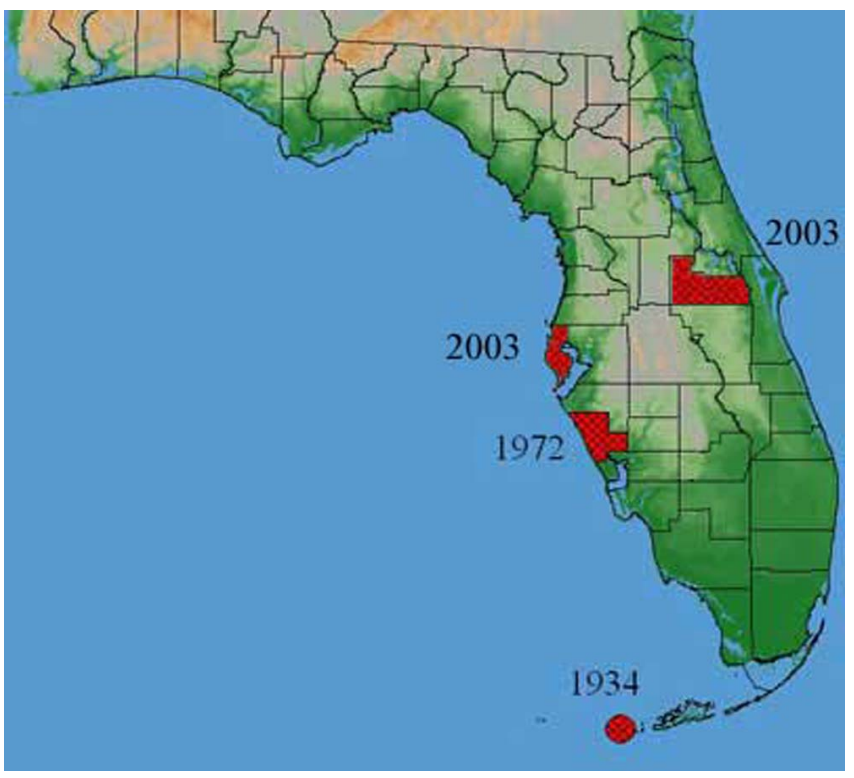

Figure 2. Incidence of the Mexican fruit fly, Anastrepha ludens (Loew), in Florida. Credits: G. J. Steck and B. D. Sutton, Division of Plant Industry

wide and extending to medial vein in suspensa), and color of thoracic setae (uniformly pale in ludens vs. dark in suspensa).

Adults may be very long-lived, up to 11 months, and highly fecund, laying 1,500 eggs or more. Extensive further details on the biology and ecology of the Mexican fruit fly are given by Baker et al. (1944); see also extensive references in Aluja (1994).

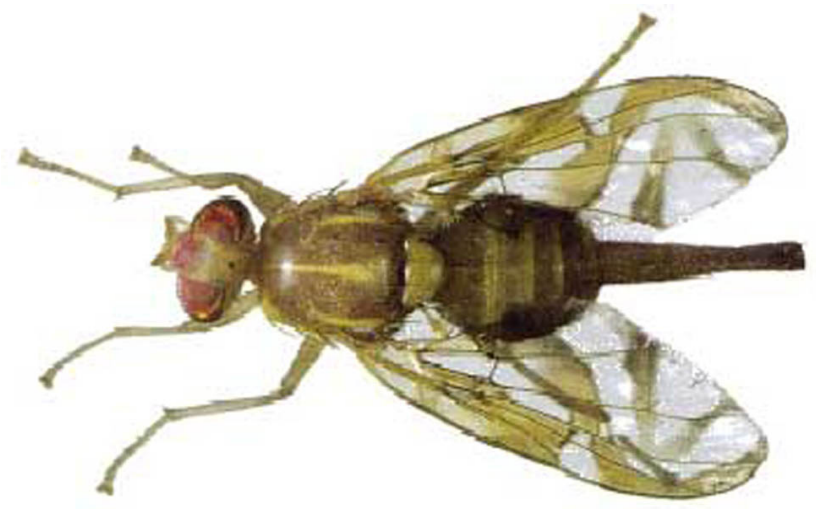

Figure 3. Adult female Mexican fruit fly, Anastrepha ludens (Loew), showing long ovipositor. Credits: Jeffrey Lotz, Division of Plant Industry

\section{Larva}

The larva is white with typical fruit fly larval shape (cylindrical, elongated, anterior end usually somewhat recurved ventrally and with mouth hooks, flattened caudal end, 8 ventral fusiform areas (1 


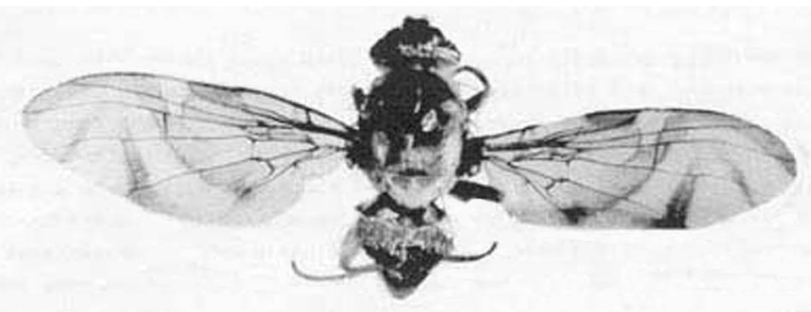

Figure 4. Adult male Mexican fruit fly, Anastrepha ludens (Loew). Credits: Division of Plant Industry

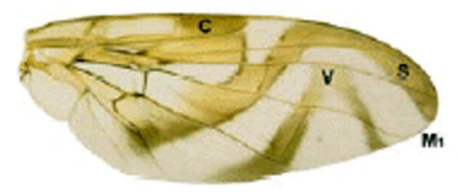

Figure 5. A. ludens wing. Credits: Jeffrey Lotz, Division of Plant Industry

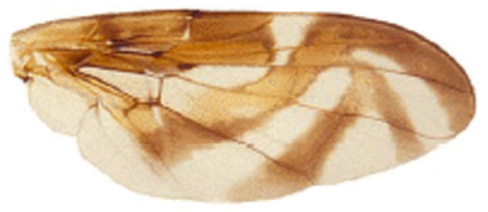

Figure 6. A. suspensa wing. Credits: Jeffrey Lotz, Division of Plant Industry

indistinct - between the thorax and abdomen), 11 segments to body); last instars usually 9 to $12 \mathrm{~mm}$ in length. Anterior buccal carinae 12 to 14 .

Cephalo-pharyngeal skeleton with relatively large convex mouth hook (length $2 \mathrm{X}$ width), with hypostome of nearly equal width; dorsal bridge enlarged; pharyngeal plate longer than dorsal wing plate and with a long pharyngeal support. Anterior spiracles slightly asymmetrical, with a median depression, usually 18 tubules present (rarely 12 to 18). Caudal end with paired dorsal (D1 \& D2) and intermediate $(11 \& 12)$ papillules, plus an indistinct I3; prominent L1 and V1; D1 \& D2 acutely angled (ca. $45^{\circ}$ ) and as widely separated as I1 \& I2; I1 \& I2 less acutely angled (ca. 30 ${ }^{\circ}$; I1, I3, and L1 approximately in a straight line (at ca. $30^{\circ}$ ) and I3 almost equidistant from L1 and I2. Posterior spiracles elongated (ca. $5 \mathrm{X}$ width), with dorsal 2 angled upward and ventral one angled downward on each side of median; interspiracular processes (hairs) mostly branched distally. Anal lobe usually bifid, but sometimes entire (the anal lobe variation requires further study to determine if this represents 1 or 2 species, or a hybrid). [Described from USNM lot from Chihuahua, Mexico.]

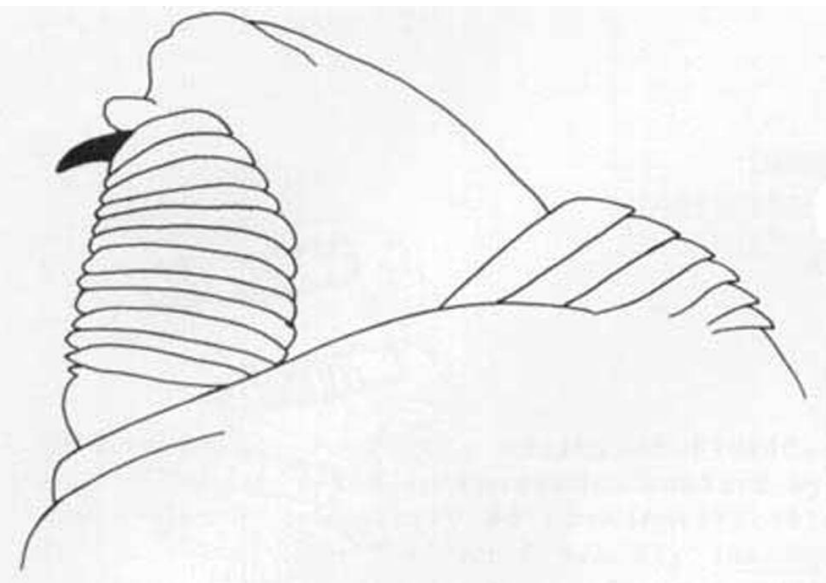

Figure 7. Buccal carinae (lateral view) of the larva of the Mexican fruit fly, Anastrepha ludens (Loew). Credits: Division of Plant Industry

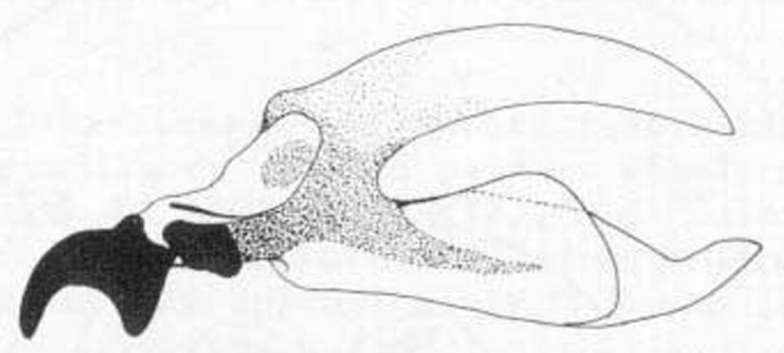

Figure 8. Pharyngeal skeleton of the larva of the Mexican fruit fly, Anastrepha ludens (Loew). Credits: Division of Plant Industry

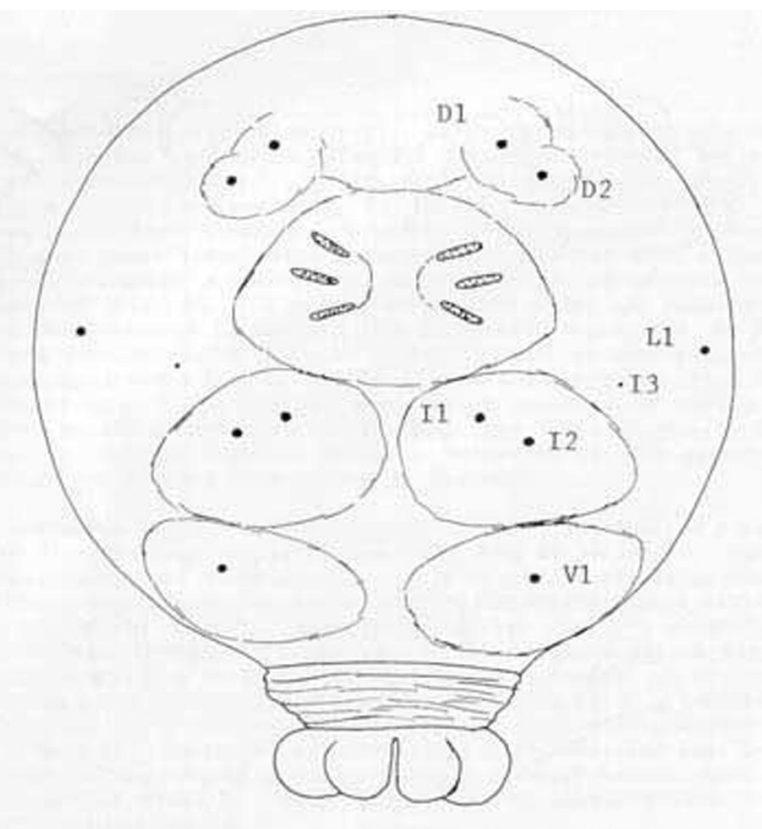

Figure 9. Caudal end of the larva of the Mexican fruit fly, Anastrepha ludens (Loew). Credits: Jack Dykinga., USDA 


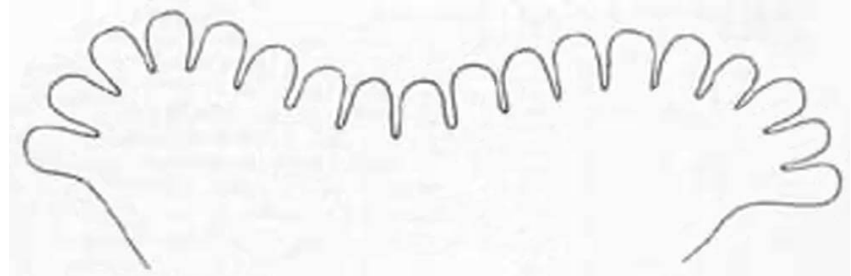

Figure 10. Anterior spiracles of the Mexican fruit fly larva.

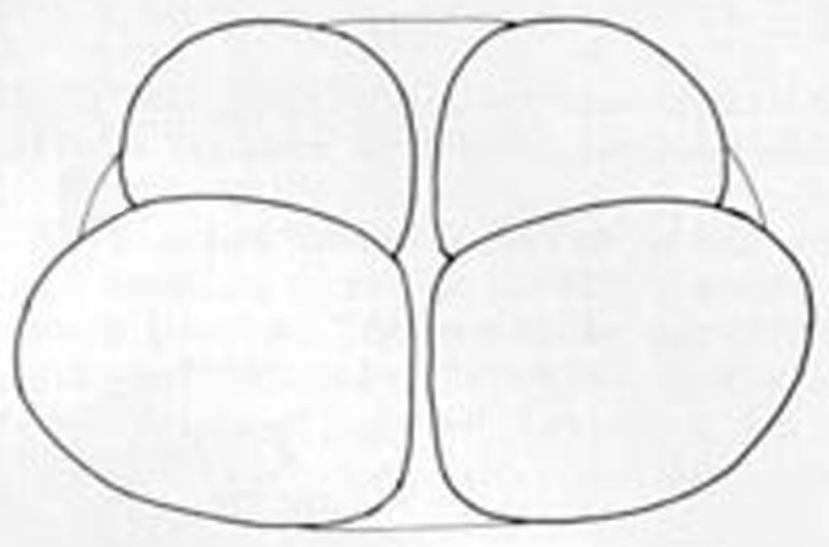

Figure 11. Anal lobes of the Mexican fruit fly larva.

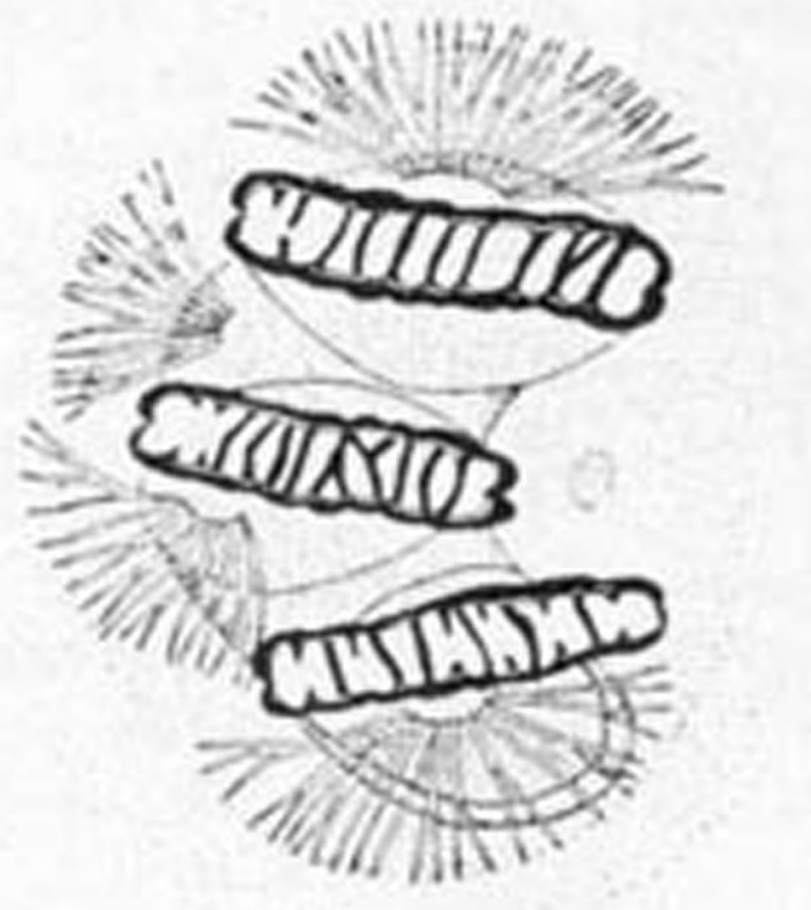

Figure 12. Posterior spriacles (left group) of the Mexican fruit fly larva.

Accurate larval identification of $A$. ludens and other species of Anastrepha is difficult. Mexican fruit fly and Caribbean fruit fly, Anastrepha suspensa
(Loew), larvae (last instars) may be separated as follows:

1. Anal lobes usually bifid (each lobe split); buccal carinae 12 to 14 ; anterior spiracles usually with 18 tubules (rarely 12 to 18); caudal end with dorsal papillules in each pair as widely separated as in each pair of intermediate papillules (distance between D1 \& D2 = I1 \& I2), and "lateral" papillules apparently only "single" (papillule I3 not prominent); ventral papillules prominent; posterior spiracles elongated (ca. 1 X 5) and separated medially by approximately $3 \mathrm{X}$ the length of 1 spiracle.....A. ludens

2. Anal lobes always entire; buccal carinae 8; anterior spiracles with 12 to 13 tubules; caudal end with dorsal papillules in each pair distinctly closer together than those of each pair of intermediate papillules (distance between D1 \& D2 half that of 11 \& 12), and "lateral" papillules with a distinct "pair" of papillules on each side of the posterior spiracles (13 prominent); ventral papillules usually indistinct; posterior spiracles of average length (ca. 1 X 3 ) and separated medially by approximately $2 \mathrm{X}$ the length of 1 spiracle. .... A. suspensa

The larval descriptions herein were made from reared and verified specimens from the U.S. National Museum of Natural History (USNM), Washington, and from other identified lots of larval specimens at the Florida State Collection of Arthropods (FSCA). Nonetheless, these specimens did not result in a configuration of the cephalo-pharyngeal skeleton exactly as published in illustrations of Phillips (1946) and Pruitt (1953). Various populations of each fruit fly species evidently exhibit variations in this and other characters that need to be taken into account. The main characteristics, however, of each species appear to be constant and allow relatively easy identification. The cephalo-pharyngeal skeleton is not usually examined in routine identifications because the larval specimen must be dissected before this character can be examined.

\section{Life Cycle}

The female typically oviposits in citrus and other fruit at the time when the fruit begins to show color. Eggs are usually laid in groups of ten and hatch in six 
to 12 days. The newly hatched larvae eat and burrow into the pulp of the fruit, taking on the color of their food so that when small they are overlooked easily. Many maggots may be found in a single fruit. When fully grown, the larvae emerge through conspicuous exit holes, usually after the fruit has fallen to the ground, and pupate in the soil. Larval development requires approximately three to four weeks, depending largely upon temperature conditions during these periods of development. The development is more rapid where comparatively higher temperatures prevail, and as a general rule, the shorter the period for fruit maturation the more rapid is the development of the larva.

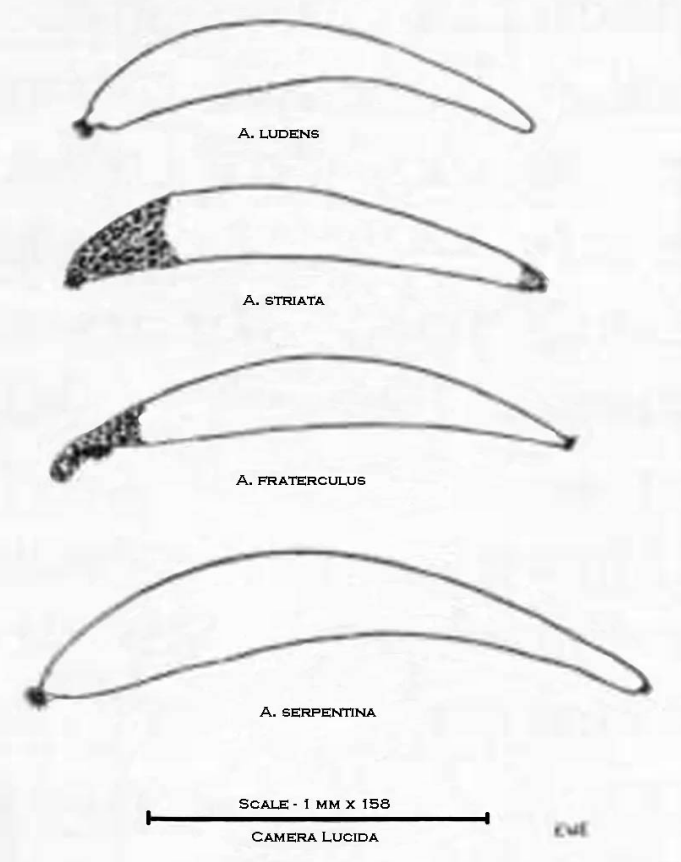

Figure 13. Egg of the Mexican fruit fly, Anastrepha ludens (Loew), compared with other common Anastrepha species. Credits: Division of Plant Industry

Adults may survive for many months, occasionally almost a full year, and males appear to be able to survive much longer than females, even as much as 16 months.

\section{Hosts}

All varieties of citrus except lemons and sour limes are attacked. Grapefruit is the preferred host, with oranges second. Pear, peach, and apple are preferred among the deciduous hosts, and white sapote and mango are preferred among the subtropical fruits. Avocado, while not a preferred host, is attacked. Other hosts include pomegranate, quince, rose apple, cherimoya, custard apple, jinicuil, mamey, and yellow chapote. Still other fruits and vegetables have been infested under laboratory conditions (Baker et al. 1944), including cacti, figs, bananas, tomatoes, peppers, squash and beans.

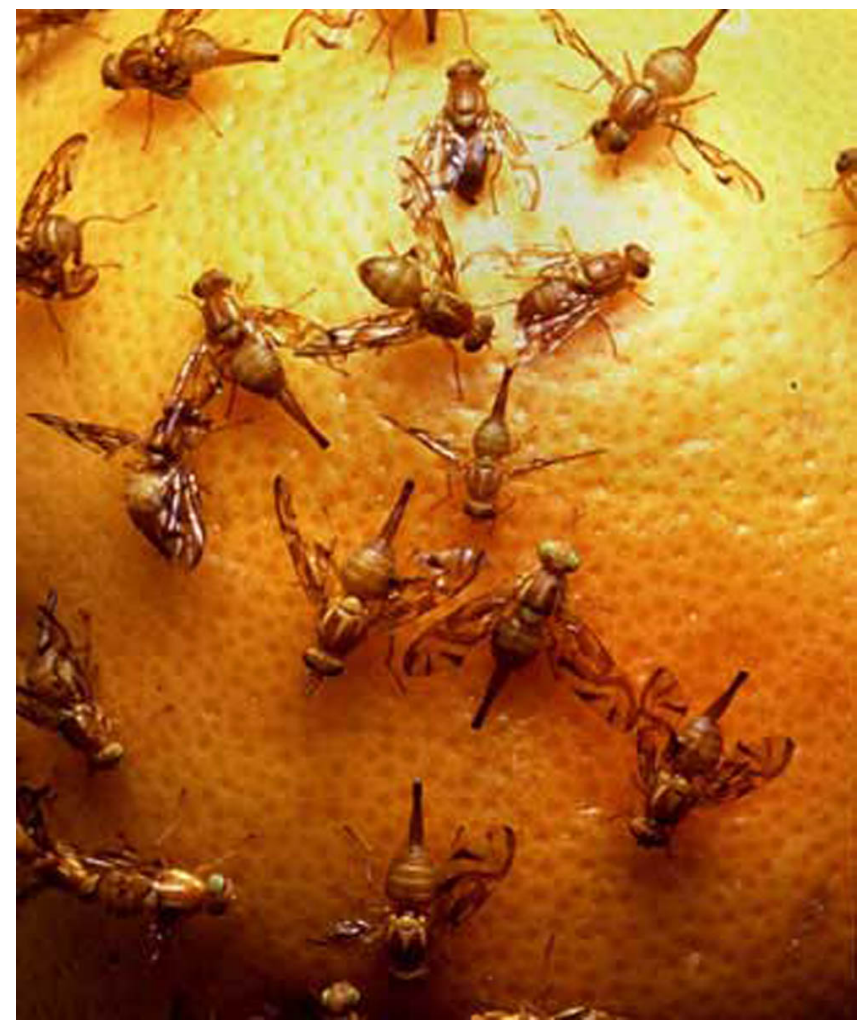

Figure 14. Mexican fruit flies, Anastrepha ludens (Loew), laying eggs in grapefruit during a laboratory test. Credits: Jack Dykinga, USDA

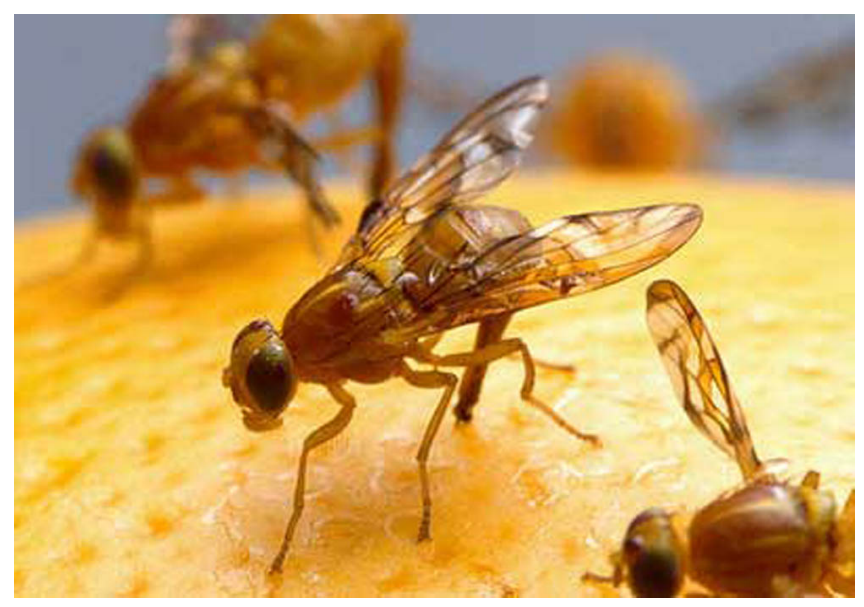

Figure 15. In grapefruit as well as many other fruits, one female Mexican fruit fly, Anastrepha ludens (Loew), can deposit large numbers of eggs: up to 40 eggs at a time, 100 or more a day, and about 2,000 over her life span. Credits: Jack Dykinga., USDA 
Anacardium occidentale - cashew

Annona cherimola - cherimoya

Annona reticulata - custard apple

Annona squamosa - sugar-apple

Carica papaya - papaya

Casimiroa edulis - white sapote

Casimiroa tetrameria - matasano

Citrus aurantiifolia - lime

Citrus maxima - pummelo

Citrus aurantium - sour orange

Citrus limetta - sweet lime

Citrus $x$ paradisi - grapefruit

Citrus medica - citron

Citrus reticulata - tangerine

Citrus sinensis - sweet orange

Coffea arabica - arabica coffee

Cydonia oblonga - quince

Diospyros kaki - Japanese persimmon

Feijoa sellowiana - feijoa

Inga spp.

Malus domestica - apple

Malus pumila - paradise apple

Mammea americana - mammey apple

Mangifera indica - mango

Mastichodendron capiri

Passiflora edulis - purple granadilla

Persea americana - avocado

Pouteria sapota - sapote
Prunus persica - peach

Psidium guajava - common guava

Psidium littorale - strawberry guava

Punica granatum - pomegranate

Pyrus communis - pear

Sargentia greggii

Spondias purpurea - red mombin

Syzygium jambos - rose-apple

List taken from White and Elson-Harris (1992) and Hernandez-Ortiz (1992).

\section{Management}

A Mexican fruit fly infestation is not readily controlled on a small scale, for example by homeowners. Egg and larval stages inside the fruit are safe from treatment. The adult stage is susceptible to poisoning, usually by a short-lived "bait spray" comprised of a contact insecticide mixed with protein and carbohydrate. This is applied as fine droplets to host plant foliage where adults feed. Adults are highly mobile, however, and move easily from any nearby untreated trees back to treated trees after a few days. On a larger commercial scale such as a citrus grove, host trees may be treated with bait spray as described above, and immigration of new adults can be minimized by removal of other host plants in a surrounding buffer area. Area-wide control is also possible using mass release of laboratory-reared and sterilized males to compete with wild fertile males and reduce the number of fertilized eggs laid.

Like other Anastrepha species, A. ludens does not respond to any known sex attractant that can be usefully employed in a detection trapping system. This is in sharp contrast to some other serious fruit fly pests, such as Mediterranean fruit fly, Ceratitis capitata (Wiedemann), and Oriental fruit fly, Bactrocera dorsalis Hendel, for which powerful male sex attractants are available and used in traps to detect populations early in the invasion process. Instead, detection systems for pest Anastrepha species rely on the use of non-specific, wet, protein-baited McPhail 
traps, which act as general food attractants, especially for young females searching for protein to produce eggs.

The Sterile Insect Technique is used in maintaining a fly-free zone in Mexico, Texas and California. Technology for the eradication programs used to maintain these zones is supported by research by the USDA ARS laboratory in Weslaco, Texas, and Sanidad Vegetal laboratories in Mexico. Both research groups cooperate with APHIS Plant Protection and Quarantine and International Services departments in establishing protocols and executing sterile insect release programs.

Trapping is not a good method to estimate populations of this fruit fly. However, cutting fruit after harvest or late season is a good method of estimating populations. If a fly is trapped in an orchard, then all fruit from that orchard is quarantined for two weeks. More sterile flies are released in the area. If a second wild fly is found than the quarantine is extended for a year. (Robacher 1993)

\section{Quarantine}

Continual detection, survey and eradication campaigns are being conducted in the cultivated citrus sections of northwestern Mexico, adjacent to California, and occasionally in the southern part of California when new invasions are detected. Sterilization of fruit before shipment from quarantined areas is required. Orange, sweet limes, grapefruit, mangos, sapotes, peaches, guavas, and plums are denied entry from Mexico into the United States by Federal Quarantine No. 5. Federal Quarantine No. 64 was enacted to prevent the shipment of certain fruits (mangos, sapotes, peaches, guavas, apples, pears, plums, quinces, apricots, mameys, ciruelas, and citrus fruits, except lemons and sour limes) from several counties in Texas to other parts of the country except under certification by the U.S. Department of Agriculture.

\section{Selected References}

Aluja M. 1994. Bionomics and management of Anastrepha. Annual Review of Entomology 39: 155-178.
Berg GH. 1979. Pictorial key to fruit fly larvae of the family Tephritidae. San Salvador: Organ. Internac. Regional Sanidad. Agropec. 36 p.

Carroll LE, and Wharton RA. 1989. Morphology of the immature stages of Anastrepha ludens (Diptera: Tephritidae). Annuals of the Entomological Society of America 82: 201-214.

Clark RA, Steck GJ, Weems Jr HW. 1996. Detection, quarantine, and eradication of exotic fruit flies in Florida, pp. 29-54. In D.L. Rosen (ed.), Pest Management in the subtropics: Integrated pest management - a Florida perspective. Intercept Ltd. Andover UK.

Dickens JC, Solis E, Hart WG. 1982. Sexual development and mating behavior of the Mexican fruit fly, Anastrepha ludens (Loew). The Southwestern Entomologist 7: 9-15.

Ebeling W. 1959. Subtropical fruit pests. University of California, Division of Agricultural Science $436 \mathrm{p}$.

Hernandez-Ortiz V. 1992. El genero Anastrepha Schiner en Mexico (Diptera: Tephritidae), Taxonomia, distribucion y sus plantas huespedes. Instituto de Ecologia, Xalapa Mexico. 162 p.

Greene CT. 1929. Characters of the larvae and pupae of certain fruit flies. Journal of Agricultural Research 38: 489-504.

Ibrahim RB. 1980. Fruit flies of Florida (Diptera: Tephritidae). Gainesville: University of Florida. 355 p. Doctoral dissertation.

Jiron LF, Soto-Manitiu J, Norrbom AL. 1988. A preliminary list of the fruit flies of the genus Anastrepha (Diptera: Tephritidae) in Costa Rica. Florida Entomologist 71:130-137.

Phillips VT. 1946. The biology and identification of trypetid larvae (Diptera: Trypetidae). Memoirs of the American Entomological Society 12:161.

Pruitt JH. 1953. Identification of fruit fly larvae frequently intercepted at ports of entry of the United States. Masters thesis. University of Florida, Gainesville. 69 p. 
Robacher D, Magan RL. 1993. ARS Program on Anastrepha species to meet APHIS Plant Quarantine requirements. University of Florida seminar.

Stone A. 1942. The fruitflies of the genus Anastrepha. USDA Miscellaneous Publications No. 439, Washington, DC. 112 p.

White IM, Elson-Harris MM. 1994. Fruit Flies of Economic Significance: Their Identification and Bionomics. CAB International. Oxon, UK. 601 p. 